\title{
PENDIDIKAN ISLAMI DALAM MENGHADAPI KEBUTUHAN ZAMAN
}

\author{
Ach. Zayyadi \\ Institut Agama Islam Nurul Jadid (IAINJ) Paiton \\ Email: achzayyadiyahoo.co.id
}

\begin{abstract}
Abstrak
Pendidikan adalah cara untuk mencerdaskan dan menyadarkan masyarakat untuk dapat hidup lebih baik. Pendidikan Islam berusaha mendidik individu mukmin agar tunduk, bertaqwa, dan beribadah dengan baik kepada Allah, sehingga memperoleh kebahagiaan di dunia dan akhirat. Perubahan yang diusahakan dalam proses pendidikan untuk menyampaikan, baik dalam tingkah laku individu, sekolah dan masyarakat. Pendidikan Islam diadakan tidak lain untuk penyempurnaan akal dan jasmani. Allah memberikan kepada manusia sesuatu kelebihan yang tidak diberikan kepada orang lain. Manusia mempunyai suatu akal yang dapat digunakan untuk berpikir, bagaimana melestarikan alam dan lingkungan, bagaimana membantu individu yang mengalami masalah. Perkembangan zaman membuat tantangan hidup semakin kompleks. Individu harus memiliki pengetahuan, pengalaman dan mental kuat untuk menjalani kehidupan untuk lebih baik. Pendidikan yang ideal adalah yang memerhatikan dimensi realitas, kapasitas, potensi fisik, intelektual dan spiritual dari individu yang seimbang dalam mendapatkan pengetahuan dari guru, lingkungan sekolah dan kesiapan mental individu. Masyarakat yang berkemampuan adalah masyarakat akademis dan profesional yang dapat menerapkan ilmu pengetahuan, teknologi dan kesenian yang merupakan kebutuhan zaman.
\end{abstract}

Kata kunci: pendidikan Islami, kebutuhan zaman

\section{Abstract}

Education is the way to educate and sensitize the public to be able to live better. Islamic Education seeks to educate the individual believer to be submissive, devoted, and pray well to God, so as to obtain happiness in this world and hereafter. Changes sought in the educational process to deliver, both in the behavior of individuals, schools and communities. Islamic education are held in another refinement of mind and the body. God gave man something advantages not given to others. Humans have a mind that can be used to think, how to preserve nature and the environment, how to help people who are having problems. The times make life increasingly complex challenges. Individuals must have the knowledge, experience and the mental strength to live a life for the better. The ideal education is 
noticed dimension of reality, the capacity, the potential for physical, intellectual and spiritual balance of the individual to obtain knowledge from the teacher, the school environment and an individual's mental readiness. People who are capable of academic and professional communities who can apply science, technology and art is a necessity of the times.

Keywords: Islamic education, era need

\section{Prolog}

Manusia tidak bisa lepas dari pendidikan. Pendidikan merupakan salah satu sektor penting dalam pembangunan di setiap negara. Menurut Undang-Undang No. 20 Tahun 2003 tentang Sisdiknas dalam pasal 1 di sebutkan bahwa pendidikan merupakan usaha sadar dan terencana untuk mewujudkan suasana belajar dan proses pembelajaran untuk mengembangkan potensi dirinya dalam memiliki kekuatan spiritual keagamaan, pengendalian diri, kepribadian, kecerdasan, akhlak mulia, serta keterampilan yang diperlukan dirinya, masyarakat, mengembangkan segala potensi yang dimiliki peserta didik melalui proses pembelajaran. Dalam pasal 4 dijelaskan bahwa peserta didik adalah anggota masyarakat yang berusaha mengembangkan potensi diri melalui proses pembelajaran yang tersedia pada jalur, jenjang, dan jenis pendidikan tertentu. ${ }^{1}$ Pengembangan pendidikan tidak hanya melihat dari pendidikan formal yang mengutamakan kepentingan dunia, tapi berusaha mengimbangi dalam pendidikan agama sebagai pondasi menghadapi kebutuhan zaman. Secara terperinci, Yūsuf Qarḍāwī memberikan definisi pendidikan Islam sebagai "proses arahan dan bimbingan untuk mewujudkan manusia seutuhnya; akal dan hatinya; rohani dan jasmaninya, akhlak dan keterampilannya sehingga mereka siap menjalani kehidupan dengan baik di manapun dan kapan pun berdasarkan nilai-nilai Islam". ${ }^{2}$

Tujuan pendidikan diutamakan sejak manusia masih dalam kandungan, lahir, hingga dewasa yang sesuai dengan perkembangan dirinya. Ketika masih kecil pun pendidikan sudah dituangkan dalam UU 20 Sisdiknas 2003, yaitu disebutkan bahwa pada pendidikan anak usia dini bertujuan untuk mengembangkan kepribadian dan potensi diri sesuai dengan tahap perkembangan peserta didik (Depdiknas 2003: 11). Dengan demikian tujuan pendidikan juga mengalami perubahan menyesuaikan dengan perkembangan manusia. Oleh karena pendidikan dialami sejak manusia lahir

\footnotetext{
${ }^{1}$ Undang-undang No. 20 Tahun 2003 tentang Sistem Pendidikan Nasional.

${ }^{2}$ Y ūsuf Qarḍāwī, Pendidikan Islam dan Madrasah Hasan Bannā, terjemah olch Bustani A.Gani, (Jakarta: Bulan Bintang, 1980), 157.
} 
hingga dewasa, maka tujuan pendidikan juga merupaka suatu proses. Proses "memanusiakan dirinya sebagai manusia" merupakan makna yang hakiki di dalam pendidikan. Keberhasilan pendidikan merupakan "cita-cita pendidikan hidup di dunia" (Dalam agama ditegaskan juga bahwa cita-cita "hidup" manusia adalah di akhirat). Akan tetapi tidak selamanya manusia menuai hasil dari proses yang diupayakan tersebut. Oleh karena itu, kadang proses itu berhasil atau kadang tidak. Jadi dengan demikian dapat dikatakan bahwa "keberhasilan" dari proses pendidikan secara makro tersebut merupakan tujuan. Keberhasilan itu juga dipengaruhi oleh beberapa faktor. Hal ini mengingat bahwa pendidikan itu ada tiga pilar yaitu pendidikan keluarga, pendidikan sekolah, dan pendidikan masyarakat. Dalam pembentukan dan tujuan pendidikan yang berkaitan dengan pembentukan watak, maka faktor keluarga sangat penting. Faktor orang tua sangat berpengaruh pada pendidikan manusia sebagai peserta didik. Kesadaran orang tua makin meningkat mengenai pentingnya pendidikan sebagai persiapan awal untuk membantu pencapaian keberhasilan pendidikan selanjutnya. Persiapan awal tersebut menyangkut pencapaian perkembangan sehat secara mental, emosi, dan sosial. Namun orang tua juga tidak sama. Seperti yag dikemukakan berikut ini bahwa kadang orang tua belum memiliki pengetahuan dan keterampilan yang memadai untuk membantu kesiapan anak untuk mengikuti pendidikan selanjutnya atau perkembangan sehat mental, emosi, sosial, dan fisik anak.

Umar bin Khattab yang mempunyai kemampuan tinggi dalam berijtihad. Umar tidak saja mengambil apa yang baik dari umat lain, tidak memandang semua perkara bersifat ta'abbudi dan tidak menghendaki sikap jumud (stagnan), tetapi mengikuti berbagai pertimbangan kemaslahatan dan melihat makna-makna yang merupakan poros penetapan hukum yang diridhai Allah. ${ }^{3}$ Landasan epistemologis, menunjukkan adanya kaitan pelaksanaan pendidikan Islam dengan situasi sosial kemasyarakatan dan tidak tercerabut dari akar sejarah. Nilai-nilai sosial kemasyarakatan dan tidak bertentangan dengan landasan utama (al-Qur'an dan Sunnah) tetap diakomodir dan menjadi bahan masukan yang berharga, dengan pertimbangan memberikan kemaslahatan kepada manusia dan menjauhkan kerusakan. Dengan dasar ini, pendidikan Islam diletakkan dalam kerangka sosiologis, selain menjadi sarana transmisi pewarisan kekayaan sosial

\footnotetext{
${ }^{3}$ Tentang dinamika pemikiran Umar didasarakan kepada pendapat al-Makky seperti dikutif Nurcholish Madjid, "taklid dan ijtihad: masalah kontinuitas dan kreativitas dalam memahami Pesan agama" dalam Budhi Rahman, (ed), Kontekstualisasi Doktrin Islam dalam Sejarah, (Jakarta: Paramadina, 1994), 346-348.
} 
budaya yang positif bagi kehidupan manusia. Moral kejujuran adalah moral universal, moral yang dijunjung tinggi oleh bangsa-bangsa modern dan beradab. Bangunan masyarakat yang sehat adalah yang didasarkan atas nilai-nilai kejujuran. Kejujuran pada gilirannya akan menumbuhkan kepercayaan (trust), dan kepercayaan merupakan salah satu unsur modal sosial. Untuk itu tugas pendidikan adalah menanamkan nilai-nilai kejujuran kepada setiap komponen di dalamnya, baik itu siswa, staf, guru maupun komponen lainnya.

Pendidikan yang berkaitan dengan cara-cara untuk menanamkan nilainilai kejujuran pada diri peserta didik melalui serangkaian cara dan strategi yang bersifat edukatif. Pendidikan mempunyai makna yang lebih luas dari pembelajaran, tetapi pembelajaran merupakan sarana yang ampuh dalam menyelenggarakan pendidikan. Jadi pembelajaran merupakan bagian dari pendidikan. Pendidikan sebagai usaha sadar yang dilakukan oleh keluarga, masyarakat dan pemerintah melalui kegiatan bimbingan, pembelajaran, dan atau latihan yang berlangsung di sekolah dan di luar sekolah. Usaha sadar tersebut dilakukan dalam bentuk pembelajaran di kelas, di mana ada pendidik yang melayani para siswanya melakukan kegiatan belajar, dan pendidik menilai atau mengukur tingkat keberhasilan belajar siswa tersebut dengan prosedur yang telah ditentukan. Proses pembelajaran merupakan proses yang mendasar dalam aktivitas pendidikan di sekolah. Dari proses pembelajaran tersebut siswa memperoleh hasil belajar yang merupakan hasil dari suatu interaksi tindak belajar yaitu mengalami proses untuk meningkatkan kemampuan mentalnya dan tindak mengajar yaitu membelajarkan siswa. Untuk lebih jelas tentang konsep pembelajaran, penulis uraikan dalam pokok bahasan tersendiri tentang pembelajaran.

Pendidikan merupakan suatu proses untuk mencapai sebuah kehidupan yang bermanfaat, karena pendidikan merupakan usaha yang sengaja dan terorganisir untuk mengkonstruk dan membantu perkembangan potensi manusia, agar nanti mengejawantahkan spesifikasi individu dan universalnya bagi kehidupan sosial. Sasaran pendidikan adalah manusia. Sebuah term yang sangat spesifik bagi manusia, karena dengan pendidikan diharapkan manusia agar mempunyai sifat humanisme yang menjadikan makhluk yang sempurna dan yang mengoptimalkan otak. Pembahasan tentang problem pendidikan di dunia sampai sekarang masih belum tuntas baik tentang mekanisme, sistem maupun aplikasinya. Teramat sulit ketika kita membicarakan masalah pendidikan, karena kesemuanya tidak terlepas dari berbagai aspek untuk dapat menunjang pelakasanaan pendidikan. Pendidikan adalah sebuah sistem konsep-konsep yang terpadu, menerangkan dan prediktif tentang peristiwa-peristiwa pendidikan. Teori pendidikan ada 
yang berperan sebagai asumsi pemikiran pendidikan dan ada yang beperan sebagai definisi menerangkan makna. Asumsi pokok pendidikan adalah pendidikan adalah aktual, artinya pendidikan bermula dari kodisi-kondisi aktual dari individu yang belajar dan lingkungan belajarnya, pendidikan adalah normatif, artinya pendidikan tertuju pada mencapai hal-hal yang baik, dan pendidikan adalah suatu proses pencapaian tujuan, artinya pendidikan berupa serangkaian kegiatan bermula dari kondisi-kondisi aktual dan individu yang belajar, tertuju pada pencapaian individu yang diharapakan.

\section{Pembahasan}

Belajar merupakan hal yang kompleks dalam proses mental untuk menghadapi segala bentuk perubahan. Konsekuensinya proses pembelajaran harus lebih memberi ruang yang luas agar individu mampu mengembangkan kualitas intelektualnya. Secara umum proses pembelajaran harus didasarkan atas asumsi umum. Proses pembelajaran adalah suatu realitas sistem. Artinya, keberhasilan pembelajaran tidak hanya ditentukan oleh satu aspek atau faktor saja, tetapi lebih ditentukan secara simultan dan komprehensif dari berbagai faktor yang ada. Proses pembelajaran adalah realitas kulturalnatural. Yaitu dalam proses pembelajaran tidak diperlukan adanya berbagai paksaan dengan dalih membentuk kedisiplinan. Pengembangan materi harus benar-benar dilakukan secara kontekstual dan relevan dengan realitas kehidupan peserta didik. Proses belajar tidak harus di dalam ruang atau gedung. Wilayah pembelajaran bisa di mana saja selama peserta didik mampu melaksanakan proses untuk mengembangkan daya analisis terhadap realitas.

\section{Pendidikan Sebagai Upaya Meneruskan Khazanah Keilmuan}

Teori pendidikan klasik berlandaskan pada filsafat klasik, seperti Perenialisme, Essensialisme, dan Eksistensialisme dan memandang bahwa pendidikan berfungsi sebagai upaya memelihara, mengawetkan dan meneruskan warisan budaya. Teori ini lebih menekankan peranan isi pendidikan dari pada proses. Isi pendidikan atau materi diambil dari khazanah ilmu pengetahuan yang ditemukan dan dikembangkan para ahli tempo dulu yang telah disusun secara logis dan sistematis. Dalam prakteknya, pendidik mempunyai peranan besar dan lebih dominan, sedangkan peserta didik memiliki peran yang pasif, sebagai penerima informasi dan tugas-tugas dari pendidik.

Shaikh al-Muhāsibi seorang sufi mengatakan bahwa akal ialah cahaya pengetahuan yang diberikan Allah kepada hati. Dengan akal seorang hamba 
dapat membedakan mana yang hak dan batil serta dapat memahami apa yang terlintas di dalam benaknya, apapun, yang baik dan yang buruk, termasuk was-was, kekhawatiran dan keinginannya. Esensi akal adalah sebuah insting yang diciptakan. Sedangkan materi akal dibagi ke dalam dua bagian yaitu akal insting dan akal eksprimen. Maka insting menghasilkan eksperimen dan dengan eksperimen akal dapat diketahui esensinya. Meskipun demikian kemampuan akal cukup terbatas. Pada dimensi ini, akal memerlukan bantuan al-qalb. Sebab dengan al-qalb tersebut, manusia dapat merasakan eksistensi immaterial dan kemudian menganalisanya lebih lanjut. Akal berhubungan dengan Intelegensi (kecerdasan). Kecerdasan dalam bahasa Inggris disebut intelligence dan bahasa Arab disebut al-dzaka menurut arti bahasa adalah pemahaman, kecepatan, dan kesempurnaan sesuatu. Dalam arti, kemampuan (al-qudrah) dalam memahami sesuatu secara cepat dan sempurna. Di dalam Islam Intelegensi disebut dengan aql atau akal yang berpusat di kepala. Akal adalah cahaya pengetahuan yang diberikan Allah kepada hati. Dengan akal seseorang hamba dapat membedakan antara yang benar dan yang salah serta dapat memahami semua yang terlintas di dalam benaknya, apapun yang baik dan yang buruk, termasuk was-was, kekhawatiran dan keinginan. Sesungguhnya hakikat akal adalah sifat atas suatu makna yang ada dalam kebenaran atau kesalahan suatu perkataan. Ia bukanlah materi dan bukan pula indra yang dapat dirasa, ia bukanlah sesuatu yang dapat dilihat. Akan tetapi akal mengetahui materi sebagaimana ia mengetahui esensi. Oleh karena itu lisan seseorang menunjukkan tingkatan akalnya jika pernyataannya benar, ia disebut orang berakal (pandai). Sebaliknya jika pernyataannya salah, ia disebut bodoh. Lisan itu menunjukkan bahwa di dalam tubuh ada cahaya yakni akal. ${ }^{4}$

Teori pendidikan ini bertolak dari asumsi bahwa sejak dilahirkan anak telah memiliki potensi-potensi tertentu. Pendidikan harus dapat mengembangkan potensi-potensi yang dimiliki peserta didik dengan bertolak dari kebutuhan dan minat peserta didik. Dalam hal ini, peserta didik menjadi pelaku utama pendidikan, sedangkan pendidik hanya menempati posisi kedua, yang lebih berperan sebagai pembimbing, pendorong, fasilitator dan pelayan peserta didik. Teori pendidikan pribadi menjadi sumber bagi pengembangan pengetahuan manusia secara humanis yaitu suatu model pengetahuan untuk menghadapi tantangan zaman yang bertujuan memperluas kesadaran diri dan mengurangi kerenggangan dan keterasingan dari lingkungan dan proses aktualisasi diri. Pengetahuan

4 Al-Muhāsibī (terj). Menuju Hadirat Illahi. Panduan bagi Khalifah Ruhani, (Bandung: Al-Bayan, 2003), 47-48. 
humanis merupakan reaksi atas pendidikan yang lebih menekankan pada aspek intelektual.

Ilmu pengetahuan menempati posisi signifikan dalam Islam. Melalui ilmu pengetahuan, manusia dibedakan dengan makhluk-makluk lain, termasuk malaikat. Oleh karena itu, ketika Allah menciptakan Adam, ia secara bersamaan membekalinya dengan pengetahuan. ${ }^{5}$ Dalam surah al Baqarah ayat 31, Allah berfirman: "Dan dia mengajarkan kepada Adam nama-nama (benda-benda) seluruhnya." (QS. Al-Baqarah [2]: 31). Teknologi pendidikan yaitu suatu konsep pendidikan yang mempunyai persamaan dengan pendidikan klasik tentang peranan pendidikan dalam menyampaikan informasi. Namun di antara keduanya ada yang berbeda. Dalam teknologi pendidikan, lebih diutamakan pembentukan dan penguasaan kompetensi atau kemampuan-kemampuan praktis, bukan pengawetan dan pemeliharaan budaya lama. Dalam teori pendidikan ini, isi pendidikan dipilih oleh tim ahli bidang-bidang khusus, berupa data-data obyektif dan keterampilanketerampilan yang mengarah kepada kemampuan vocational. Isi disusun dalam bentuk desain program atau desain pengajaran dan disampaikan dengan menggunakan bantuan media elektronika dan para peserta didik belajar secara individual. Peserta didik berusaha untuk menguasai sejumlah besar bahan dan pola-pola kegiatan secara efisien tanpa refleksi. Keterampilan-keterampilan barunya segera digunakan dalam masyarakat. Guru berfungsi sebagai direktur belajar, lebih banyak tugas-tugas pengelolaan dari pada penyampaian dan pendalaman dalam menghadapi interaksi global.

Pendidikan interaksional yaitu suatu konsep pendidikan yang bertitik tolak dari pemikiran manusia sebagai makhluk sosial yang senantiasa berinteraksi dan bekerja sama dengan manusia lainnya. Pendidikan sebagai salah satu bentuk kehidupan juga berintikan kerja sama dan interaksi. Dalam pendidikan interaksional menekankan interaksi dua pihak dari guru kepada peserta didik dan dari peserta didik kepada guru. Lebih dari itu, dalam teori pendidikan ini, interaksi juga terjadi antara peserta didik dengan materi pembelajaran dan dengan lingkungan, antara pemikiran manusia dengan lingkungannya. Interaksi terjadi melalui berbagai bentuk dialog. Dalam pendidikan interaksional, belajar lebih sekadar mempelajari fakta-fakta. Peserta didik mengadakan pemahaman eksperimental dari fakta-fakta tersebut, memberikan interpretasi yang bersifat menyeluruh serta memahaminya dalam konteks kehidupan. Filsafat yang melandasi pendidikan interaksional yaitu filsafat rekonstruksi sosial manusia.

\footnotetext{
${ }^{5}$ Abd A’la, Pembaruan Pesantren, (Yogyakarta: LKiS), 34
} 
Para ahli filsafat pendidikan, menyatakan bahwa dalam merumuskan pengertian pendidikan sebenarnya sangat tergantung kepada pandangan terhadap manusia, hakikat, sifat-sifat atau karakteristik dan tujuan hidup manusia itu sendiri. Perumusan pendidikan tergantung kepada pandangan hidupnya. Apakah manusia dilihat sebagai kesatuan badan dan jasmani, jiwa dan roh atau jasmani dan rohani? Pertanyaan-pertanyaan di atas, memerlukan jawaban yang menentukan pandangan terhadap hakikat dan tujuan pendidikan, dan dari sini juga sebagai pangkal perbedaan rumusan pendidikan atau timbulnya aliran-aliran pendidikan seperti, pendidikan Islam, Kristen, Liberal, Progresif atau Pragmatis, Komunis, Demokratis dan lain-lain. Dengan demikian, terdapat keanekaragaman pandangan tentang pendidikan. Tetapi dalam keanekaragaman pandangan tentang pendidikan terdapat titik persamaan tentang pengertian pendidikan, yaitu pendidikan dilihat sebagai suatu proses. Proses adalah kegiatan mengarahkan perkembangan seseorang sesuai dengan nilai-nilai yang merupakan jawaban atas pertanyaan di atas. Maka, proses pendidikan hanya berlaku pada makhluk manusia tidak pada hewan.

Pendidikan dengan keseluruhan proses (general process) yang dibawanya, dapat diajukan sebagai helper bagi manusia dalam mengejawantahkan kehidupannya. Karenanya, pendidikan menempati central position yang strategis dalam rangka mengkonstruk kehidupan individu dan sosial yang diharapkan mampu memposisikan kehidupan bersamaan dengan pluralitas kehidupan makro manusia itu sendiri. Bahkan, urgensitas pendidikan semakin tampak jelas dengan masuknya eksistensi dan esensi manusia ke dalam dimensi ruang dan waktu kehidupan umat manusia menjelang masuknya new revival age (millennium III). ${ }^{6}$

\section{Hakikat Pendidikan Islam Memanusiakan Manusia}

Hakikat pendidikan Islam adalah konsep berpikir tentang kependidikan yang bersumberkan atau berlandaskan ajaran-ajaran agama Islam tentang hakikat kemampuan manusia untuk dapat dibina dan dikembangkan serta dibimbing menjadi manusia Muslim yang seluruh pribadinya dijiwai oleh ajaran Islam. Sedangkan menurut Omar Muhammad al-Taomi $\bar{i}$ al-Shaibāní, pendidikan Islam tidak lain ialah pelaksanaan pandangan Islam dalam bidang pendidikan yang didasarkan pada ajaran Islam. Pendidikan Islam itu merupakan kajian secara filosofis mengenai berbagai masalah yang terdapat dalam kegiatan pendidikan yang didasarkan

\footnotetext{
${ }^{6}$ Nizamia, Jurnal Pendidikan dan Pemikiran Islam, Vol.5, No. 1, Januari-Juni 2002,
} 60 . 
pada al-Qur' an dan al-Hadis sebagai sumber primer, dan pendapat para ahli, khususnya para filosof muslim, sebagai sumber sekunder. ${ }^{7}$ Perilaku yang disandarkan terhadap ajaran Islam akan mendapatkan kemapanan dan ketegasan dalam menghadapi segala bentuk persoalan, karena Islam telah memiliki rambu-rambu yang jelas kebenarannya untuk memanusiakan manusia.

Tilaar (2002: 435) menyatakan bahwa "hakikat pendidikan adalah memanusiakan manusia, yaitu suatu proses yang melihat manusia sebagai suatu keseluruhan di dalam eksistensinya". Mencermati pernyataan dari Tilaar tersebut dapat diperoleh gambaran bahwa dalam proses pendidikan, ada proses belajar dan pembelajaran, sehingga dalam pendidikan jelas terjadi proses pembentukan manusia yang lebih manusia. Proses mendidik dan dididik merupakan perbuatan yang bersifat mendasar (fundamental), karena di dalamnya terjadi proses dan perbuatan yang mengubah serta menentukan jalan hidup manusia. Dalam tujuan pembangunan, pendidikan merupakan sesuatu yang mendasar terutama pada pembentukan kualitas sumber daya manusia. Pembangunan sumber daya manusia berarti perlunya peningkatan pengetahuan, keterampilan dari kemampuan semua orang dalam suatu masyarakat. ${ }^{8}$ Tujuan pendidikan memuat gambaran tentang nilai-nilai yang baik, luhur, pantas, benar, dan indah untuk kehidupan. Melalui pendidikan selain dapat diberikan bekal berbagai pengetahuan, kemampuan dan sikap juga dapat dikembangkan berbagai kemampuan yang dibutuhkan oleh setiap anggota masyarakat sehingga dapat berpartisipasi dalam pembangunan. Tujuan pokok pendidikan adalah membentuk anggota masyarakat menjadi orang-orang yang berpribadi, berperikemanusiaan maupun menjadi anggota masyarakat yang dapat mendidik dirinya sesuai dengan watak masyarakat itu sendiri, mengurangi beberapa kesulitan atau hambatan perkembangan hidupnya dan berusaha untuk memenuhi kebutuhan hidup maupun mengatasi problematikanya. Metode pembelajaran tidak dilakukan secara monoton, metode yang bervariasi merupakan tuntutan mutlak dalam proses pembelajaran. Keterlibatan siswa secara aktif dalam belajar amat dipentingkan, karena dengan mengaktifkan siswa, maka proses asimilasi dan akomodasi pengetahuan dan pengalaman dapat terjadi dengan baik. Belajar memahami akan lebih bermakna dari pada belajar menghafal. Agar bermakna, informasi baru harus disesuaikan dan dihubungkan dengan pengetahuan yang telah dimiliki siswa. Tugas guru adalah menunjukkan hubungan antara apa yang sedang dipelajari dengan apa yang telah diketahui

\footnotetext{
${ }^{7}$ Abuddin Nata, Paradigma Pendidikan Islam (Jakarta: Grasindo, 2001), 14-15

${ }^{8}$ Tilaar, H.A.R, Manifesto Pendidikan Nasional, (Jakarta: Kompas, 2005), 435
} 
siswa. Pembelajaran harus memperhatikan perbedaan individual siswa, faktor ini sangat mempengaruhi keberhasilan belajar siswa. Perbedaan tersebut misalnya pada motivasi, persepsi, kemampuan berfikir, pengetahuan awal dan sebagainya.

Menurut Horton dan Hunt dalam Bungin, mobilitas sosial dapat diartikan sebagai suatu gerak perpindahan dari suatu kelas sosial ke kelas sosial lainnya. Mobilitas bisa berupa peningkatan atau penurunan dalam segi status sosial dan (biasanya) termasuk pula segi penghasilan yang dapat dialami oleh beberapa individu atau oleh keseluruhan anggota kelompok. Secara umum ada tiga jenis mobilitas sosial, yaitu gerak sosial yang meningkat (sosial climbing), gerak sosial menurun (sosial sinking), dan gerak sosial horizontal. Ketiga jenis mobilitas sosial ini dapat dialmi oleh sipa saja dan kapan saja sesuai dengan bagaimana seseorang mengekspresikan lingkungan sosial dan bagaimana lingkungan sosial mengekspresikan seseorang secara timbal balik. Littejohn dalam Bungin, tujuan humanitas adalah memahami respon subjektif individual. Sains adalah suatu aktivitas "di luar sana" sedangkan humanitas menekankan "di dalam sini". Sains berfokus pada dunia penemuan, humanitas berfokus pada orang penemu. Sains berupaya mencari konsensus, humanitas berupaya mencari interpretasi-interpretasi alternatif. Pada humanis sering merasakan ingin tahu terhadap pernyataan bahwa ada suatu dunia kekal untuk ditemukan. Pakar humanitas cenderung tidak memisahkan "siapa seseorang" menunjukkan "apa yang dilihatnya" karena penekanannya pada respons subjektif. Pengetahuan humanisti teristimewa cocok terhadap problem seni, pengalaman pribadi, dan nilai-nilai. Hampir semua program riset dan penyusunan teori menyertakan beberapa aspek, baik pengetahuan ilmah maupun pengetahuan humanistik. Pada suatu saat ilmuwan adalah seorang humanis yang menggunakan intuisi kreativitas, interpretasi, dan pandangan dengan ironis. Ilmuwan menjadi objektif dalam menciptakan metode yang mengarah kepada observasi objektif, mambuat riset, merancang suatu proses kreatif. Dengan demikian, pada suatu saat ilmuwan menjadi humanis pada gilirannya harus ilmiah, berupaya mencari fakta yang dapat dipahami. ${ }^{9}$

Manusia adalah makhluk sosial, maka manusia pada dasarnya tidak mampu hidup sendiri di dalam dunia ini, baik sendiri dalam konteks fisik maupun dalam konteks sosial budaya. Terutama dalam konteks sosialbudaya, manusia membutuhkan manusia lain untuk saling berkolaborasi dalam pemenuhan kebutuhan fungsi-fungsi sosial satu dengan lainnya.

\footnotetext{
${ }^{9}$ Bungin, H.H.Burhan, Sosiologi Komunikasi, (Jakarta: Kencana Prenada Group,
} 2006), 50 . 
Karena pada dasarnya suatu fungsi yang dimiliki oleh manusia satu akan sangat berguna dan bermanfaat bagi manusia lainnya. Karena fungsi-fungsi sosial yang diciptakan oleh manusia ditujukan untuk saling berkolaborasi dengan sesama fungsi sosial manusia lainnya dengan kata lain, manusia menjadi sangat bermartabat apabila bermanfaat baik manusia lainnya. Fungsi-fungsi sosial manusia lahir dari kebutuhan akan fungsi tersebut oleh orang lain. Dengan demikian, produktivitas fungsional dikendalikan oleh berbagai macam kebutuhan manusia. Setiap manusia memiliki kebutuhan masing-masing secara individual maupun kelompok, untuk memenuhi kebutuhan-kebutuhan tersebut, maka perlu adanya perilaku selaras yang dapat diadaptasi oleh masing-masing manusia. Penyelarasan kebutuhan dan penyesuaian kebutuhan individu, kelompok dan kebutuhan sosial satu lainnya, menjadi konsentrasi utama pemikiran manusia dalam masyarakat yang beradab.

Tindakan awal dalam penyelarasan fungsi-fungsi sosial dan berbagai kebutuhan manusia diawali oleh dan dengan melakukan interaksi sosial atau tidakan komunikasi satu dengan yang lainnya. Aktivitas interaksi sosial dan tindakan komunikasi itu dilakukan baik secara verbal, non-verbal maupun simbolis. Kebutuhan adanya sebuah sinergi fungsional dan akslerasi positif dalam melakukan pemenuhan kebutuhan manusia satu dengan lainnya ini kemudian melahirkan kebutuhan tentang adanya norma-norma dan nilainilai sosial yang mampu mengatur tindakan manusia dalam memenuhi berbagai kebutuhannya, sehingga tercipta keseimbangan sosial (social equilibrium) antara hak dan kewajiban dalam pemenuhan kebutuhan manusia, terutama juga kondisi keseimbangan itu akan menciptakan tatanan sosial (social order) dalam proes kehidupan masyarakat saat ini dan waktu yang akan datang. Interaksi sosial dalam berkelompok dan bermasyarakat, yang oleh babermas disebut dengan tindakan komunikasi ini merupakan perspektif sosiologi, dan perspektif ini pula yang menjadi objek pengamatan sosilogi komunikasi. Fokus interaksi sosial dalam masyarakat adalah komunikasi itu sendiri. Sebagaimana dijelaskan oleh sosiologi bahwa komunikasi menjadi unsur terpenting dalam seluruh kehidupan manusia. Dominasi perspektif ini dalam sosiologi yang begitu luas dan mendalam, maka lahirlah kebutuhan untuk mengkaji kekhususan dalam studi-studi sosiologi yang dinamakan sosiologi komunikasi, yaitu perspektif kajian sosiologi tentang aspek-aspek khusus komunikasi dalam lingkungan individu, kelompok, masyarakat, budaya, dan dunia. 


\section{Pendidikan untuk Masyarakat Lebih Islami}

Ibn Khaldun mengatakan, bahwa pendidikan merupakan upaya perubahan potensi (al-Taqat al-Quswa) manusia. Jadi pendidikan memegang peranan penting dalam tamadun manusia. Ibn Khaldun menjelaskan manusia sebagaimana makhluk hewani lainnya juga mempunyai sifat hayawaniyätnya seperti al-hiss (rasa), al-harakat (gerak), memerlukan al-qizä',(makanan) dan tempat tinggal (al-kanni). Manusia berbeda dengan makhluk lain karena manusia mampu untuk berpikir. Dengan potensi itu manusia dapat mencari keperluan hidup. Dengan potensinya, manusia dapat berinteraksi dengan sesamanya untuk tujuan-tujuan kesejahteraan hidup bersama. Juga dengan potensinya, manusia dapat menerima ajaran-ajaran dari Allah yang disampaikan oleh para Nabi kepadanya. ${ }^{10}$

Ki Hajar Dewantoro dalam Padil, memberdayakan semua unsur masyarakat untuk membangun pendidikan dalam masyarakat ada tiga. Pribadi manusia akan selalu berada dan mengalami perkembangan dalam tiga lembaga pendidikan yaitu: keluarga, sekolah dan masyarakat. Ketiga lembaga ini secara bertahap dan terpadu mengemban tanggungjawab pendidikan bagi generasi mudanya. Kemudian, tripusat pendidikan ini dijadikan prinsip pendidikan, bahwa pendidikan berlangsung seumur hidup. Keluarga bisa diartikan sebagai a group of two or more persons residing together who are related by hood, marriag, or adoption. Keluarga mempunyai arti penting dalam kehidupan manusia dalam kehidupan di masyarakat. Terbentuknya keluarga bukan semata-mata mempunyai kepentingan yang sama, tetapi lebih dari itu adalah berdasarkan sukarela dan cinta kasih yang asasi di antara dua manusia (suami-istri). Berdasarkan rasa cinta kasih inilah kemudian lahir anak sebagai generasi penerus. Keluarga juga sangat penting sebagai wadah antara individu dan kelompok yang menjadi tempat pertama dan utama untuk sosialisasi anak. Ibu, ayah, saudara, dan keluarga yang lain adalah orang yang pertama bagi anak untuk mengadakan kontak dan tempat pembelajaran sebagaimana hidup orang lain. Anak-anak menghabiskan waktunya dalam keluarga, sampai mereka masuk sekolah. Dalam lembaga pendidikan keluarga melahirkan atau menciptakan fungsi dan peran keluarga, nilai pendidikan dalam keluarga, proses pendidikan dalam keluarga dan peran keluarga dalam pendidikan anak.

10 Ibn Khaldun dalam konteks ini lebih suka menggunakan istilah al-Ta'Tim daripada al-Tarbiyāt. Meskipun kedua istilah itu berbeda, namun pengertian alTa'Tim dalam terminologi Ibn Khaldūn adalah pendidikan. Para ahli pendidikan Islam menggunakan istilah al-Ta'Tim yang bererti pendidikan. Tokoh-tokoh tersebut misalnya al-Zarnüjì (w. 602.H/1223.M). 
Sekolah berasal dari bahasa Belanda school, bahasa Jerman die scrule, bahas inggris school yang artinya sama dengan sekolah, yaitu suatu lembaga pendidikan. Dalam kehidupan sehari-hari, kata sekolah mempunyai banyak arti. Sekolah dapat diartikan sebagai gedung tempat belajar, waktu berlangsungnya pelajaran dan usaha menuntut pelajaran kegiatan belajar mengajar. Terlepas dari pengertian ini, sekolah merupkan lembaga pendidikan formal sebagai tempat belajar siswa. Sekolah mempunyai dua aspek penting yaitu aspek individu dan aspek sosial. Di satu pihak, pendidikan sekolah bertugas mempengaruhi dan menciptakan kondisi yang memungkinkan perkembangan pribadi anak secara optimal. Di pihak lain, pendidikan sekolah bertugas mendidik anak agar mengabdikan dirinya kepada masyarakat. Sekolah sebagai lembaga pendidikan formal dituntut untuk dapat merekam segala fenomena yang terjadi di masyarakat. Dalam lembaga pendidikan sekolah akan memberikan fungsi sekolah, kebudayaan sekolah dan aspek-aspek pokok pendidikan sekolah.

Masyarakat dapat diartikan sebagai suatu bentuk dengan tata kehidupan sosial dengan tata nilai dan tata budaya sendiri. Dalam arti ini, masyarakat adalah wadah dan wahana pendidikan. Dalam arti yang terperinci, masyarakat adalah sekelompok manusia yang menempati daerah tertentu, menunjukkan integrasi berdasarkan pengalam bersama berupa kebudayaan memiliki sejumlah lembaga yang melayani kepentingan bersama mempunyai kesadaran dan kesatuan tempat tinggal dan dapat bertindak bersama. Dalam pengertian ini menunjukkan betapa pentingnya arti masyarakat dan kehidupan manusia, sebab manusia tidak mungkin dapat hidup sendiri dan tidak dapat berdiri sendiri tanpa kerjasama dan bantuan orang lain. Masyarakat sangat penting artinya bagi kehidupan manusia. Setidaknya dalam masyarakat itu ada dua hal yang sesuai dengan kebutuhan dan keinginan manusia, yaitu sistem nilai dan struktur kekuasaan. Nilai sosial sangat erat dengan jati diri manusia, sehingga menurut William bahwa nilai-nilai sosial selalu dijunjung tinggi oleh orang banyak. Nilai sosial apabila sudah disepakati melaui konsensus oleh orang banyak, maka nilainilai tersebut dipandang sebagai hal yang menyangkut kesejahteraan bersama. Nilai sosial selalu berorientasi pada peningkatan kualitas hidup manusia. Nilai akan selalu melekat pada etika dan moral masyarakat, sehingga apa yang menjadi kebutuhan atau cita-cita yang dianggap baik oleh masyarakat luas, menjadi pedoman dalam hidup bersama di masyarakat. 
Lembaga pendidikan masyarakat memiliki peran dalam lembaga sekolah masyarakat, lembaga keagamaan, lembaga ekonomi dan lembaga politik. ${ }^{11}$

Pendidikan merupakan salah satu indikator utama pembangunan dan kualitas sumber daya manusia, sehingga kualitas sumber daya manusia sangat tergantung dari kualitas pendidikan. Pendidikan merupakan bidang yang sangat penting dan strategis dalam pembangunan nasional, karena merupakan salah satu penentu kemajuan suatu bangsa. Pendidikan bahkan merupakan sarana paling efektif untuk meningkatkan kualitas hidup dan derajat kesejahteraan masyarakat, serta yang dapat mengantarkan bangsa mencapai kemakmuran. Dari segi etimologis, pendidikan berasal dari bahasa Yunani "paedagogike". Ini adalah kata majemuk yang terdiri dari kata "pais" yang berarti "anak" dan kata "ago" yang berarti "aku membimbing". Jadi paedagogikeberarti aku membimbing anak. Orang yang pekerjaan membimbing anak dengan maksud membawanya ke tempat belajar, dalam bahasa Yunani disebut "paedagogos". Pendidikan seperti yang diungkapkan dalam Kamus Besar Bahasa Indonesia diartikan sebagai proses pengubahan sikap dan tata laku seseorang atau sekelompok orang dalam usaha mendewasakan manusia melalui upaya pengajaran dan pelatihan. Pengertian teori pendidikan adalah teori yang digunakan dalam proses belajar mengajar. Salah satu penerapan teori belajar yang terkenal adalah teori dari John Dewey yaitu teori "learning by doing". Teori belajar ini merupakan subordinat dari teori pendidikan. Karenanya sebelum membahas teori belajar tersebut, perlu diuraikan pengertian teori pendidikan. Teori merujuk pada suatu usaha untuk menjelaskan bagaimana sesuatu terjadi seperti adanya. Selain itu teori juga merupakan usaha untuk menjelaskan sesuatu yang mungkin terjadi di masa datang. Pengertian ini mengandung makna bahwa fungsi teori adalah melakukan prediksi. Teori juga diartikan sebagai kebalikan dari sebuah praktek. Jika dihubungkan dengan pendidikan maka teori pendidikan merupakan seperangkat penjelasan yang rasional sistematis membahas tentang aspek-aspek penting dalam pendidikan sebagai sebuah sistem. Teori pendidikan adalah sebuah pandangan atau serangkaian pendapat ihkwal pendidikan yang disajikan dalam sebuah sistem konsep. Pendidikan sebagai sistem mengandung arti suatu kelompok tertentu yang setidaknya memiliki hubungan khusus secara timbal balik dan memiliki informasi.

Kattsoff mengatakan manusia memang merupakan suatu obyek penyelidikan yang berharga, karena ia sendiri yang menyelidiki dirinya dan

${ }^{11}$ Padil, Moh. Supriyatno, Triyo, Sosiologi Pendidikan. (Malang: UIN-Malang Press, 2007), 24 
pikirannya dikacaukan oleh dirinya sendiri. Banyak jumlah di dalam segala bahasa membuktikan bahwa manusia mempersoalkan dirinya sendiri. Di bawah ini terdapat beberapa di antaranya tersebut:

a. "manusia dan binatang kedua-duanya persis sama"

b. "setiap manusia merupakan suatu kemustahilan sampai saat ia dilahirkan"

c."manusia ialah sebuah mesin yag diberi makan dan menghasilkan pikiran".

d. "manusia hanya merupakan hasil karya besar Tuhan."

e."manusia hanyalah sebatang ilalang sesuatu yang paling lemah di alam raya, namun ia adalah ilalang yang berfikir"

f. "manusia yang mulia merupakan sekadar citra Tuhan".

Kita akan mengajukan pertanyaan yang kritis, bahkan sebelum mempertimbangkan makna-makna yang dikandung oleh istilah-istilah yang bersangkutan. Pertanyaan tersebut ialah: "apakah yang kita maksudkan dengan pertanyaan itu sendiri?" Dengan kata lain, bila kita menanyakan "apakah manusia itu?" Maka apakah yang ingin kita ketahui? Macam jawaban apakah dapat memuaskan kita? Metode-metode penyelesaian manusia. Ada berbagai cara mengawali penyelidikan tentang manusia. kita dapat menentukan bagaimana cara orang memakai istilah "manusia", atau kita apat melihat contoh-contoh tentang manusia dan berusaha menentukan apakah yang mereka miliki bersama. Di dalam masing-masig pendekatan tersebut kesukaran-kesukaran. Kita mungkin menaruh keberatan dengan mengatakan, sering orang menggunakan istilah tersebut dengan cara yang menyesatkan. Dan ini agaknya memang benar, karena itu kita perlu menyaring orang-orang yang menggunakan istilah tersebut yang maknanya dapat kita terima; artinya, mereka yang berdasarkan alasan-alasan tertentu menurut pendapat kita mengetahui apa makna istilah tersebut dan memakainya secara tepat.

Selanjutnya, bisa juga orang menggunakan istilah "manusia" secara tepat ditinjau dari segi tata bahasa, namun tidak mengetahui apa makna yang dikandungnya; artinya, ia tidak dapat mendefinikan istilah tersebut. Yang demikian ini juga merupakann suatu ungkapan pikiran yang sah, tetapi kita perlu membahas bukan bagaimana istilah itu dipergunakan, melainkan keadaan-keadaan di mana istilah itu dipakai untuk menyimpulkan makna yang sudah dianggap terdapat di dalam penggunaan istilah tersebut. Mudah dilihat, ini sebenarnya sesuai dengan metode kedua untuk menyelidiki manusia. Metode ketiga untuk menyelidiki manusia ialah dengan jalan meneliti apa yang telah dikerjakan oleh manusia dan apa yang telah mereka hasilkan, dan kemudian berusaha menyimpulkan hakekat penghasil tersebut 
berdasarkan hasil yang telah diperolehnya. Dengan demikian, sejarah, ilmu purbakala, dan ilmu manusia akan banyak peranannya dalam membantu kita untuk memahami manusia. ${ }^{12}$

\section{Pendidikan dan Kesenjangan Sosial}

Pembiayaan pendidikan yang menimbulkan (atau makin mengukuhkan) kesenjangan dalam masyarakat. Minimnya tanggung jawab dan peran pemerintah dalam bidang pendidikan akan makin mengukuhkan segregasi siswa berdasarkan status sosio-ekonomi. Siswa-siswa dari keluarga miskin yang mendapat subsidi pemerintah tidak akan mampu menanggung kekurangan biaya sehingga mereka akan terpaksa mencari dan terkonsentrasi di sekolah-sekolah yang minimalis dimana biaya operasional per-anak tidak jauh melebihi subsidi minimal yang diberikan pemerintah. Siswa-siswa dari kelas menengah dan atas bebas memilih sekolah dengan sarana dan prasarana yang memadai karena mereka tidak keberatan membayar kekurangannya. Selanjutnya, karena sekolah-sekolah ini mendapatkan iuran pendidikan yang memadai dari siswa, sekolah-sekolah ini juga akan mempunyai lebih banyak keleluasaan untuk makin membenahi diri dan meningkatkan mutu pendidikan. Besarnya anggaran tidak menamin peningkatan mutu pendidikan di suatu sekolah. Namun kekurangan anggaran hampir pasti sanga menghambat peningkatan mutu pendidikan. Dalam jangka waktu panjang, disparitas sekolah miskin dan kaya serta anak miskin dan kaya akan makin lebar. Bahkan, di beberapa daerah banyak sekolah miskin harus ditutup karena memang sudah tidak mampu lagi membiayai penyelenggaraan pendidikan. Proses pendidikan dilakukan setidaknya dapat mengetahui kualifikasi untuk menyesuaikan dengan kebutuhan dan kemampuan individu di zaman yang serba teknologi.

Gibson dan Mitchell secara umum, penempatan pendidikan agak berbeda dari bentuk penempatan lain karena ia menyajikan upaya terorganisasikan untuk mencocokkan kualifikasi individu plus minat dan sumber daya pribadi dengan persyaratan lembaga dan programnya. Biasanya, konselor sekolah, dengan tanggung jawab bagi penempatan kuliah dan pendidikan tinggi lainnya, menyediakan siswa informasi terkait persyaratan masuk, biaya, karakteristik program dan isinya. Mereka juga sering kali membantu siswa melegkapi bentuk aplikasi yang dibutuhkan. Teknologi dewasa ini juga menyediakan bagi siswa akses yang mudah lewat Web bagi informasi ekstensif tentang lembaga pendidikan tinggi dan semua

12 Kattsoff, Louis O. Pengantar Filsafat. (Yogyakarta: Tiara Wacana Yogyakarta 1992), 398. 
aspeknya. Salah satu contoh format yang digunakan konselor untuk siswa SMU yang tertarik melanjutkan ke jenjang pendidikan tinggi. Penempatan pendidikan di sekolah tempat mereka bekerja. Dalam kapasitas ini, mereka harus bisa menempatkan siswa berdasarkan kurikulum dan pelajaran yang tepat. Namun begitu, aktivitas penjadwalan yang terdiri utamanya dari proses mekanis yang dirancang untuk menempatkan semua siswa ke semua slot di waktu tertentu, tanpa mengindahkan perbedaan dan keunikan siswa, tidak bisa dianggap sebagai bimbingan yang bertanggung jawab, bahkan meski konselor melaporkan kalau mereka sudah menghabiskan banyak waktu melakukannya.

Di dalam literature, minimal, kalau bukan selalu dalam praktiknya, penempatan di dalam lembaga-lembaga pendidikan sudah dilihat lebih dari sekadar karier, kuliah dan penempatan pendidikan. Dalam pengertiannya yang paling luas, penempatan merupakan sebuah aktivitas yang meletakkan atau memfasilitasi penempatan diri pribadi-pribadi ke situasi atau lingkup yang akan memampukan mereka memetik manfaat dari pengalaman yang dibutuhkan, membuat penyesuaian yang memuaskan, mendapatkan informasi yang berguna, dan secara umum, memberikan kontribusi bagi perkembangan totalnya. Sebagai contoh bagi konsep yang lebih luas bagi penempatan, mari kita membahas penempatan yang berfokus kepada memberikan seseorang pengalaman di beragam peran dan lingkungan yang berbeda. $^{13}$

Pendidikan adalah proses dua arah yang melibatkan pemberian pengetahuan sebagai upaya pemberian petunjuk dan peringatan, serta sekaligus upaya perolehan pengetahuan untuk mendapatkan ketakwaan, bukan menonjolkan diri dan keangkuhan (intelektual). ${ }^{14}$ Penempatan peran mengasumsikan kalau mengalami peran yang berbeda dan signifikan sangat penting bagi semua siswa yang tengah berkembang. Meskipun banyak yang akan mengalami beberapa perang ini secara alamiah dan tanpa rencana, namun mayoritas kesempatan perkembangan ini akan terlewatkan kecuali pembagian khusus sudah dibuat. Ini adalah kesempatan lain bagi konselor sekolah dan guru kelas untuk bekerja secara kooperatif untuk merencanakan pengalaman bermakna yang meningkatkan program instruksi dan pengembangan pribadi siswa. Pengalaman peran yang signifikan akan mencakup peluang untuk berfungsi secara periodis sebagai pemimpin, anggota tim, pekerja individu, guru, orang-orang yang berprestasi, individu

\footnotetext{
${ }^{13}$ Gibson, Robert L., Mitchell, Marianne H, Bimbingan dan Konseling, (Yogyakarta: Pustaka Pelajar, 2011), 491-492.

${ }^{14}$ Abd A'la, Pembaruan Pesantren, (Yogyakarta: LKiS), 37.
} 
yang bertanggung jawab, makhluk sosial, individu yang punya otoritas dan pengambilan keputusan, atau seseorang yang melayani orang lain untuk mencerdaskan seorang anak dengan memberikan fasilitas yang memadai.

Siraev dan Levy mengatakan anak-anak minoritas, sepanjang yang kita ketahui, menunjukkan nilai rendah pada tes kecerdasan dan keterampilan kognitif lainnya. Dengan asumsi tes itu tidak bias ke kelompok cultural tertentu, dan anak emiliki kemampuan bahasa yang cukup unttuk memahami soal tes, apa yang dapat dilakukan guru dan orang tua untuk meningkatkan performa tes anak? Studinya tentang psikologi AfrikaAmerika, mengatakan bahwa ada beberapa cara yang bisa dipakai orang dewasa untuk meningkatkan nilai tes kecerdasan anak-anak minoritas mengatakan bahwa meski banyak anak minoritas kekurangan pengalaman developmental karena kemiskinan, rumah yang sesak, dan parenting yang tidak memadai defisit ini dapat diatasi. Untuk itu, beberapa anak mungkin butuh guru yang memerhatikan fungsi kognitifnya. Bagi anak lain, mungkin perlu diberi perhatian ekstra pada konteks emosi di mana pembelajaran intelektul berlangsung. Misalnya, adalah bermanfaat untuk membuat lingkungan kelas yang kooperatif, dan mengajak orang tua dalam proses pendidikan. Jika prosedur pemecahan problem intelektual menggunakan tantangan yang menarik dan menyenangkan, anak-anak besar kemungkinan akan menyukai situasi akdemik dan lebih sering terlibat dalam aktivitas ketimbang sebelumnya. Problemnya adalah bahwa banyak anak minoritas mulai merasakan kompetensi di situasi non-akademik, terutama dalam konteks permainan di jalan. Dengan kata lain, jalananlah yang lebih sering membentuk keterampilan anak, bukan guru. ${ }^{15}$

Tugas paling sulit bagi keluarga dan guru melibatkan orang-orang dalam proses pendidikan. Secara keseluruhan, pada skala dunia, kesuksesan ini tidak banyak. Akan tetapi, banyak kasus menunjukkan kemungkinan interaksi itu. Mengembangkan pendidikan khusus, berbasis komunitas, dengan melibatkan ibu local, training interaktifnya mencakup analisis tugas kognitif special dan diskusi kelompok dwi-mingguan tentang anak mereka, problem mereka, dan komunikasi orangtua-anak. Kultur adalah atribut tak terpisahkan dari kesadaran manusia-kesadaran subjektif seseorang atas sensasinya, persepsinya, dan berbagai aktivitas mentalnya. Kesadaran adalah proses yang melalui beberapa tahap atau keadaan. Aliran kesadaran "normal" mungkin terdiri dari periode perhatian dan konsentrasi penuh atau pengabaian terhadap kejadian di luar. Periode bangun diubah oleh periode

${ }^{15}$ Shiraev, Eric B., Levy David A, Psikologi Lintas Kultural. (Jakarta: Kencana 2012), 444-445 
tidur. Dalam berbagai macam kondisi, aliran kesadaran normal dapat diubah melalui meditasi, zat psikoaktif, keadaan trance, atau sugesti hipnotis. Tetapi, konsep dasar kesadaran adalah rumit, dan karenanya analisidnya dalam kontek lintas cultural terjadi.

Zuhairini menyatakan bahwa pendidikan adalah usaha yang diarahkan kepada pembentukan kepribadian anak sesuai dengan ajaran Islam atau sesuatu upaya dengan ajaran Islam, berfikir, merumuskan dan berbuat berdasarkan nilai-nilai Islam, serta bertanggungjawab sesuai dengan nilainilai Islam. ${ }^{16}$ Dalam kenyataannya, kemampuan fungsional manusia dapat dilakukannya secara simultan dalam kehidupan sehari-hari sebagai makhluk individu, makhluk sosial, dan sebagai makhluk spiritual. Namun juga manusia dengan kecerdasannya dapat memisahkan fungsi-fungsi tersebut berdasarkan pada kepentingan dan kebutuhan serta kondisi sosial yang mengitarinya. Kemampuan-kemampuan fungsional inilah yang menjadikan manusia berbeda secara fundamental dengan makhluk-makhluk hidup yang lainnya di muka bumi ini. Bahkan dengan kekuatan spiritualnya maka manusia mampu mengungguli kemampuan makhluk-makhluk Allah lainnya seperti Jin dan sebagainya. kekayaan pengalaman manusia menjadi faktafakta empris. Prinsip bebas nilai positivisme talah membuat ilmuwan menjadi robot-robot tak berperasaan. Positivisme telah mengakibatkan keringnya semesta dari kekayaan batin yang tak terhingga, semesta telah didesakralisasi. ${ }^{17}$ Tahapan filsafat yang terakhir ini merupakan reaksi keras terhadap positivisme terutama pada asumsi kesatuan metode untuk ilmuilmu alam maupun ilmu-ilmu manusia. Metode positivistik mengasumsikan bahwa objek-objek alam maupun manusia bergerak secara deterministikmekanis. Manusia lebih dari sekadar benda mati yang bergerak semata-mata berdasarkan stimulant dan respons, rangsangan dan reaksi, sebab akibat (behaviorurime). Manusia, menurut Ernes Cassirer adalah makhluk yang memiliki substratum simbolis dalam benaknya hingga mampu memberikan jarak antara rangsangan dan tanggapan. Distensiasi (refleksi) tersebut melahirkan apa yang disebut sistem-sistem simbolis, seperti ilmu pengetahuan, seni, religi dan sosial.

\section{Prolog}

Pendidikan mengajarkan tentang persoalan hidup yang mesti dihadapi manusia dengan sikap dan perilaku yang benar dalam menjalaninya. Manusia

\footnotetext{
${ }^{16}$ Zuhairini, Filsafat Pendidikan Islam. (Jakarta: Bumi Aksara, 1995), 152.

${ }^{17}$ Bungin, H.H.Burhan, Sosiologi Komunikasi. (Jakarta: Kencana Prenada Group, 2006), 10.
} 
Pendidikan islami dalam menghadapi

kebutuhan zaman

adalah ciptaan Tuhan yang diberikan tanggungjawab besar karena manusia adalah makhluk ciptakan Allah, Tuhan Yang Maha Esa dengan struktur dan fungsi yang sempurna bila dibandingkan dengan makhluk Tuhan lainnya. Manusia juga diciptakan sebagai makhluk multidimensional, memiliki akal pikiran dan kemampuan beriteraksi secara personal maupun sosial. Karena itu, manusia disebut sebagai makhluk yang unik, yang memiliki kemampuan sosial sebagai makhluk indivdu dan makhluk sosial. di samping itu, semua manusia dengan akal pikirannya mampu mengembangkan kemampuan tertingginya sebagai makhluk ciptaan Tuhan yaitu memiliki kemampuan spiritual, sehingga manusia di samping sebagai makhluk individual, makhluk sosial, juga sebagai makhluk spiritual. Pendidikan Agama Islam adalah upaya sadar dan terencana dalam menyiapkan peserta didik untuk mengenal, memahami, menghayati hingga mengimani, bertaqwa, dan berakhlak mulia dalam mengamalkan ajaran agama Islam dari sumber utamanya kitab suci al-Qur'an dan Hadis, melalui kegiatan bimbingan, pengajaran, latihan, serta penggunaan pengalaman. Dibarengi tuntunan untuk menghormati penganut agama lain dalam hubunganya dengan kerukunan antar-umat beragama dalam masyarakat hingga terwujud.

\section{Daftar Pustaka}

A'la, Abd. Pembaruan Pesantren. Yogyakarta: LkiS, 2006.

David A, Shiraev, Eric B., Levy. Psikologi Lintas Kultural. Jakarta: Kencana, 2012.

Dimyati \& Mudjiono. Belajar dan Pembelajaran. Jakarta: PT Rineka Cipta 2002.

H.H.Burhan, Bungin. Sosiologi Komunikasi. Jakarta: Kencana Prenada Group, 2006.

H.A.R, Tilaar. Manifesto Pendidikan Nasional. Jakarta: Kompas, 2005.

Louis O, Kattsoff. Pengantar Filsafat. Yogyakarta: Tiara Wacana Yogyakarta, 1992.

Marianne H, Gibson, Robert L., Mitchell. Bimbingan dan Konseling. Yogyakarta: Pustaka Pelajar, 2011.

Al-Muhāsibi (terj). Menuju Hadirat Illahi. Panduan bagi Khalifah Ruhani, Bandung: Al-Bayan, 2003.

Nata, Abuddin. Paradigma Pendidikan Islam. Jakarta: Grasindo 2001.

Nizamia. Jurnal Pendidikan dan Pemikiran Islam, Vol.5, No. 1, Januari-Juni 2002. 
Pusat Pengembangan Kurikulum. Kurikulum 2004 Kerangka Dasar (draft). Jakarta: Departemen Pendidikan Nasional Dewantara, Ki Hadjar. 1961. Karya Ki Hadjar.Yogyakarta: Taman Siswa, 2003.

Qarḍāwī, Yūsuf. Pendidikan lslam dan Madrasah Hasan al-Bannā, terjemah oleh Bustani A. Gani, Jakarta: Bulan Bintang, 1980.

Rahman, Budhi. (ed), Kontekstualisasi Doktrin Islam dalam Sejarah, Jakarta: Paramadina, 1994.

Sodiq A, Kuntoro. "Hubungan antara beberapa Faktor Guru, Strategi, Intruksional, dan Hasil Belajar Siswa taman Kanak-kanak". Disertasi S3. Fakultas Pasca Sarjana Institut Keguruan dan Ilmu Pendidikan Jakarta. Maret, 1988.

Triyo, Padil, Moh., Supriyatno. Sosiologi Pendidikan. UIN-Malang Press, 2007.

Undang-undang No. 20 Tahun 2003 tentang Sistem Pendidikan Nasional.

Zuhairini. Filsafat Pendidikan Islam. Jakarta: Bumi Aksara, 1995. 